\title{
Rancang Bangun Aplikasi Dilib-Us (Digital Library) Berbasis Android Menggunakan Metode Prototyping
}

\author{
Yustina Meisella Kristania1, Joko Dwi Mulyanto ${ }^{2}$ \\ STMIK Nusa Mandiri Jakarta ${ }^{1}$, STMIK Nusa Mandiri Jakarta ${ }^{2}$ \\ yustina.yms@nusamandiri.ac.id ${ }^{1}$, joko.jdm@nusamandiri.ac.id ${ }^{2}$
}

\begin{abstract}
Human life, both directly and indirectly, has been influenced by developments in the field of information and communication technology, one of which is in the library field. The library is one place where information and knowledge are easily obtained. But now libraries are still more often found in physical form where access to locations is still an obstacle. There are still many libraries that only provide a collection of printed books, making it difficult in the search process, and need more space to accommodate the collection of books. The manual lending and repayment process causes services to be less effective and efficient. The author tries to create an android application-based library system with the name Dilib-Us where there are search, loan and return features that can improve the quality of library services. This system applies the data collection method and prototype method as a system development model. The purpose of this study is to facilitate service users in finding information on libraries through the Dilib-Us application. It is expected that this application can provide facilities for prospective borrowers in the process of borrowing and returning books and for librarians in processing data, such as: adding, changing and deleting data.
\end{abstract}

Keywords: library; borrowing; system; information; android; prototype

Abstrak - Kehidupan manusia, baik secara langsung maupun tidak langsung, telah dipengaruhi oleh perkembangan di bidang teknologi informasi dan komunikasi, salah satunya adalah di bidang perpustakaan. Perpustakaan adalah satu tempat di mana informasi dan pengetahuan mudah diperoleh. Namun kini perpustakaan masih lebih sering ditemukan dalam bentuk fisik di mana akses ke lokasi masih menjadi kendala. Masih banyak perpustakaan yang hanya menyediakan koleksi buku cetak, sehingga menyulitkan dalam proses pencarian, dan membutuhkan lebih banyak ruang untuk menampung koleksi buku. Proses peminjaman dan pembayaran manual menyebabkan layanan menjadi kurang efektif dan efisien. Penulis mencoba membuat sistem perpustakaan aplikasi berbasis android dengan nama Dilib-Us di mana terdapat fitur pencarian, pinjaman dan pengembalian yang dapat meningkatkan kualitas layanan perpustakaan. Sistem ini menerapkan metode pengumpulan data dan metode prototipe sebagai model pengembangan sistem. Tujuan dari penelitian ini adalah untuk memfasilitasi pengguna layanan dalam mencari informasi tentang perpustakaan melalui aplikasi Dilib-Us. Diharapkan aplikasi ini dapat memberikan fasilitas bagi calon peminjam dalam proses peminjaman dan pengembalian buku serta bagi pustakawan dalam mengolah data, seperti: menambah, mengubah, dan menghapus data.

Kata kunci: perpustakaan; peminjaman; sistem ; informasi ; android; prototipe

\section{PENDAHULUAN}

Perkembangan bidang teknologi informasi dan komunikasi pada saat ini telah membawa manfaat yang sangat penting bagi kemajuan kehidupan manusia. Dengan adanya perkembangan teknologi informasi tersebut maka secara tidak langsung juga berpengaruh terhadap kehidupan manusia, termasuk dalam bidang perpustakaan. Perpustakaan adalah salah satu tempat dimana informasi dan ilmu pengetahuan mudah didapat.(Nawi \& Yuhanef, 2007). Namun perpustakaan yang ada saat ini, lebih banyak dijumpai dalam bentuk fisik atau konvensional dimana lokasi dan akses menjadi kendala untuk mengunjungi perpustakaan. Perpustakaan juga hanya menyediakan koleksi buku-buku berformat cetak, sehingga menjadi hal yang menyulitkan dewasa ini dalam mencari buku atau sumber referensi yang dibutuhkan, serta memerlukan ruangan yang besar untuk menampung koleksi buku-buku baik itu yang lama maupun yang baru. Proses peminjaman dan pengembalian yang juga masih manual menyebabkan pelayanan pada perpustkaan dirasa juga menjadi kurang efektif dan efesien. Dijaman globalisasi saat ini masyarakat cenderung menginginkan hal yang praktis, mudah, dan akurat sehingga menuntut perpustakaan dilengkapi teknologi informasi dan komunikasi yang memadai. Melihat akan kebutuhan tersebut, penulis mencoba membuat suatu rancang bangun sistem perpustakaan berbasis aplikasi android bernama Dilib-Us, dimana terdapat fitur pencarian, peminjaman dan pengembalian yang dapat memberi kemudahan pengguna dalam mencari dan mendapatkan informasi yang dibutuhkan guna meningkatkan mutu pelayanan perpustakaan. Rancang bangun sistem ini menerapakan beberapa metode, yaitu metode pengumpulan 
data dan metode prototype sebagai model pengembangan system yang digunakan terdiri dari tahapan mendemonstrasikan konsep, percobaan rancangan, dan menemukan masalah dan solusi. Tujuan dari penelitian ini adalah untuk memudahkan para pengguna layanan dalam pencarian informasi pada perpustakaan melalui aplikasi Dilib-Us. Diharapkan dengan adanya aplikasi ini dapat memberikan kemudahan bagi calon peminjam dalam melakukan proses peminjaman dan pengembalian buku serta bagi pustakawan dalam mengolah data.

\section{TINJAUAN PUSTAKA}

Pada bagian ini penulis akan menjelaskan beberapa tinjauan pustaka yang berkaitan dengan penelitian ini, yaitu

\subsection{Konsep Electronic Library (eLibrary)}

Yang membedakan antara "perpustakaan biasa" dengan "perpustakaan elektronik" adalah terletak pada keberadaan koleksi. Koleksi yang ada perpustakaan elektronik tidak harus berada pada tempat fisik, sedangkan koleksi buku pada perpustakaan biasa terletak pada sebuah tempat yang menetap, yaitu perpustakaan.(Subrata, 2010). Perbedaan berikutnya adalah terletak padai konsep perpustakaan itu sendiri dimana perpustakaan elektronik menerapkan internet dan komputer sebagai media akses dan pengolahan data dan informasi, sedangkan konsep perpustakaan biasa adalah koleksi buku-buku diletakan pada suatu tempat. Berikutknya perpustakaan elektronik bisa diakses pembaca dimana saja dan kapan saja, sedangkan untuk perpustakaan biasa, pembaca harus terlebih dahulu mengatur jadwal yang telah ditetapkan oleh organisasi perpustakaan.

\subsection{Aplikasi Android}

Dalam salah satu sumber dikatakan bahwa, Android adalah adalah perangkat lunak yang digunakan untuk tujuan tertentu, seperti mengolah dokumen, mengatur Windows \&, permainan (game) dan sebagainya. (Hakim, 2012)

Dengan menggunakan sistem operasi android yang sifatnya merupakan open source, memungkinkan banyak aplikasi dapat dimodifikasi dan disalurkan secara bebas.

Sejak diperkenalkan pada tahun 2007, Android mempunyai beberapa varian atau versi. yang terbaru adalah versi OS Android 10 yang diperkenalkan pada 29 Agustus 2019 lalu.

\section{METODOLOGI PENELITIAN}

Metode pengembangan perangkat lunak yang digunakan dalam penelitian ini adalah metode penelitian prototyping. Langkah-langkah Prototyping dimulai dengan pengumpulan kebutuhan, melibatkan pengembang dan pengguna sistem untuk menentukan tujuan, fungsi dan kebutuhan operasional sistem. (Ogedebe \& Jacob, 2012)

Langkah-langkah dalam prototyping adalah sebagai berikut :

1. Pengumpulan Kebutuhan. 2. Proses desain yang cepat. 3. Membangun prototipe. 4. Evaluasi dan perbaikan.

Dalam pengembangan sistem diperlukan penentuan kebutuhan awal seperti menganalisa ide dan gagasan untuk membangun sistem.(Purnomo, 2017). Analisis juga diperlukan untuk mengetahui komponen yang berjalan pada sistem. Memasuki tahapan berikutnya yaitu desain, diperlukan untuk mengetahui bagaimana sistem akan memenuhi tujuannya untuk dibangun. Hasil dari desain sistem adalah berupa sebuah spesifikasi sistem yang dapat berupa konsep desain interface, proses dan data dengan tujuan menghasilkan spesifikasi sistem yang sesuai dengan kebutuhan. Dengan melalukan pengujian terhadapa sistem, harapannya sistem mampu berjalan sesuai dengan perencanaan dan desain yang telah dibuat sebelumnya.

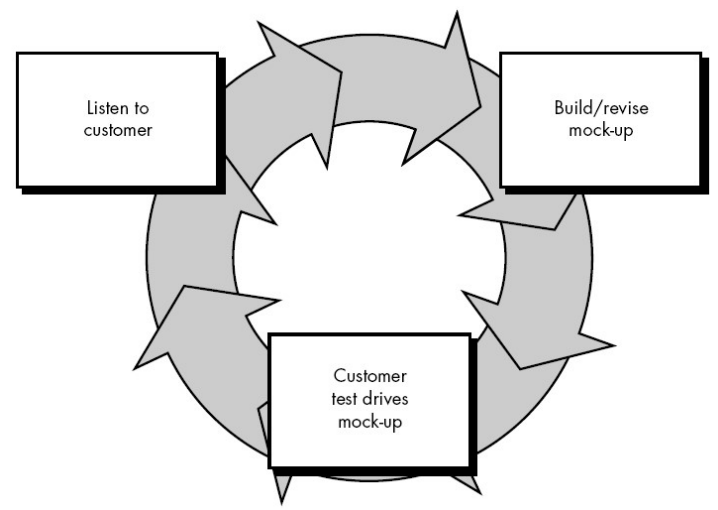

Sumber : (Ogedebe \& Jacob, 2012) Gambar 1. Model Prototype

\section{HASIL DAN PEMBAHASAN}

\section{Analisis PIECES (Performance, Information, Economy, Control, Eficiency and Service)}

Metode PIECES adalah metode analisis sebagai dasar untuk memperoleh pokokpokok permasalahan yang lebih spesifik. Ketika sebuah sistem dianalisa, bakan dilakukan terhadap beberapa aspek yaitu, kinerja, informasi, ekonomi, keamanan aplikasi, efisiensi dan pelayanan pelanggan.(Ragil, 2010)

\subsection{Performance (Kinerja)}

Sebagai tolak ukur apakah proses yang ada masih dapat ditingkatkan kinerjanya, serta melihat sejauh mana sistem dapat menghasilkan tujuan yang diharapkan. Pada aplikasi Dilib-Us ini, transaksi (peminjaman dan pengembalian) dilakukan hanya melalu Perpustakaan dengan versi buku cetak saja, yang terbatas tempat dan waktu. Dengan 
aplikasi ini akan membuat proses transaksi tidak terbatas waktu dan dapat dilakukan dimana saja. Sehingga melalui kinerja yang meningkat, tujuan dari sistem ini dapat tercapai.

\subsection{Information (Informasi)}

Informasi yang disajikan harus mempunyai nilai guna. Informasi buku-buku yang ada selama ini hanya dapat diperoleh dengan langsung mengunjungi Perpustakaan. Dengan bantuan aplikasi Dilib-Us ini, informasi dapat terakses dengan lebih mudah. Maka kualitas informasi yang dihasilkan menjadi semakin baik.

\subsection{Economics (Nilai Guna dan Biaya)}

Pada Perpustakaan yang berjalan selama ini media pengenalan buku-buku yang ada masih memakan waktu dan biaya. Dengan menggunakan aplikasi Dilib-Us ini pengenalan terhadap buku-buku yang tersedia cukup dengan mengupload informasi buku (katalog) memalui aplikasi tersebut. Sehingga nilai guna dapat ditingkatkan dan biaya penyelenggaraan dapat diturunkan.

\subsection{Control (Kualitas Kontrol)}

Saat ini semua aktifitas pada Perpustakaan masih terbilang hanya dilakukan secara offline. Proses Transaksi (peminjaman dan pengembalian) akan semakin mudah dengan dilakukan secara online melalui aplikasi DilibUS. Maka kualitas kontrol dan kemampuan untuk mendeteksi kekeliruan juga semakin baik.

\subsection{Efficiency (Efisiensi)}

Informasi dan pengenalan yang berjalan pada Perpustakaan masih menggunakan hard copy sehingga masih memakan waktu yang cukup lama dalam menyampaikan pesan kepada calon peminjam buku. Dengan menggunakan aplikasi Dilib-Us, penyampaian informasi menjadi lebih cepat dan dapat diakses setiap saat. Sehingga mampu meningkatkan keefisiensian operasi dari sistem yang lama.

\subsection{Services (Pelayanan)}

Pelayanan pada Perpustakaan selama ini masih kurang maksimal, karena calon peminjam masih diharuskan untuk datang setiap kali hendak meminjam atau mengembalikan buku. Dengan pelayanan yang diberikan oleh aplikasi Dilib-Us ini, proses transaksi dapat dilakukan oleh setiap calon peminjam tanpa harus datang langsung. Maka kemampuannya untuk mencapai peningkatan kualitas layanan dapat diperbaiki.

\section{Perancangan Dilib-Us Bagi Pengguna 2.1. Kebutuhan Pengguna}

Tahap awal terdapat menu pendaftaran yang wajib diisi oleh pengguna atau user untuk menjadi anggota perpustakaan Dilib-Us. Kemudian tersedia menu login untuk menggunakan aplikasi Dilib-Us dengan memasukan email beserta password. Lalu user akan dibawa ke tampilan menu home.

\subsection{Kebutuhan Admin}

Admin dapat melihat data peminjaman yang berisi (data anggota dan data buku yang dipinjam). Jika daftar buku yang dpinjam oleh pengguna tidak tersedia maka admin akan mengirim pemberitahuan pada pengguna bahwa buku yang diminta tidak tesedia. Berikutnya, admin akan mengontrol waktu peminjaman, 3 hari sebelum jatuh tempo pengembalian admin akan mengirim pemberitahuan dan apabila sudah melebihi jatuh tempo pengembalian akan dikenakan denda.

\section{Model Konseptual}

Model konseptual atau kerangka konseptual suatu penelitian adalah suatu model konseptual yang menunjukkan hubungan logis antara faktor/variabel yang telah diidentifikasi penting untuk menganalisis masalah penelitian (Sukaria, 2014). Model konseptual dari penelitian ini adalah sebagai berikut:

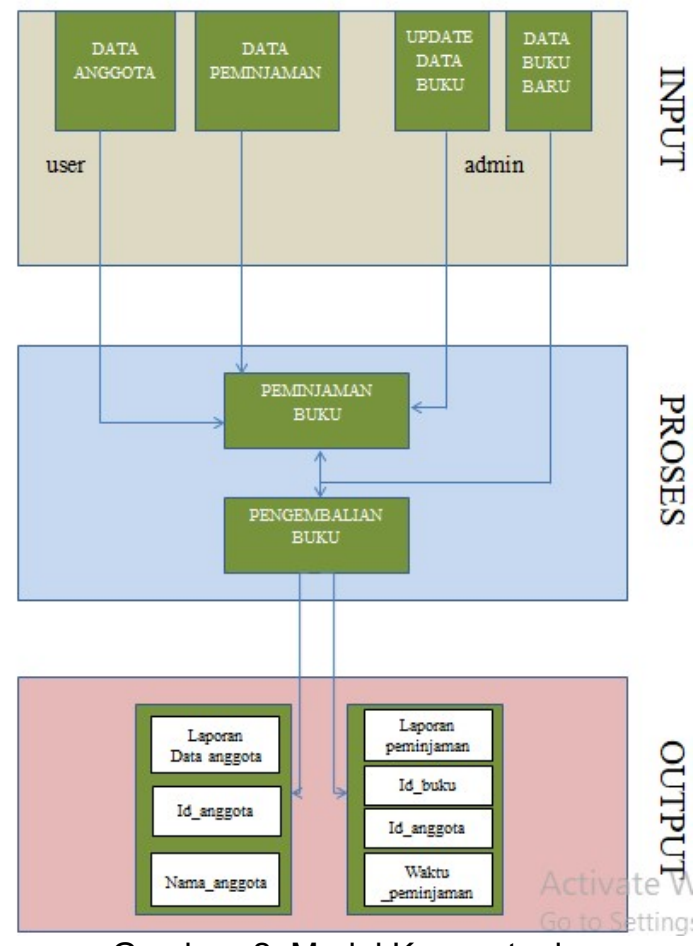

Gambar 2. Model Konseptual

\subsection{Perancangan Basis Data}

Database berfungsi sebagai penampung data yang akan dimasukkan melalui form website. Perancangan basis data dibuat untuk memberikan gambaran mengenai tabel-tabel yang akan dirancang sebagai berikut : 


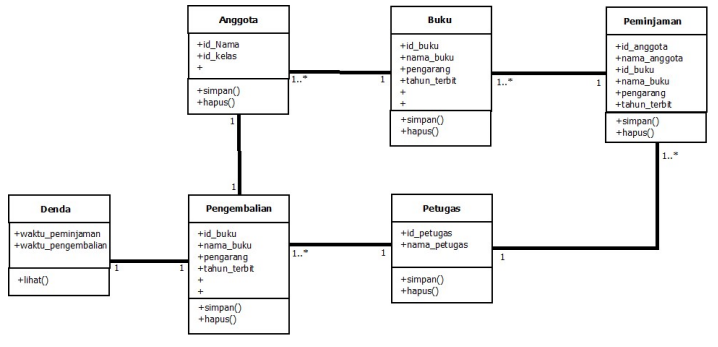

\section{Rancangan Antar Muka}

4.1.Dilib-Us Menu Login User

Pengguna log in dengan mengisi form nomor telepon/email/nama dan kata sandi lalu klik tombol masuk, apabila lupa kata sandi pengguna dapat klik tulisan lupa password.

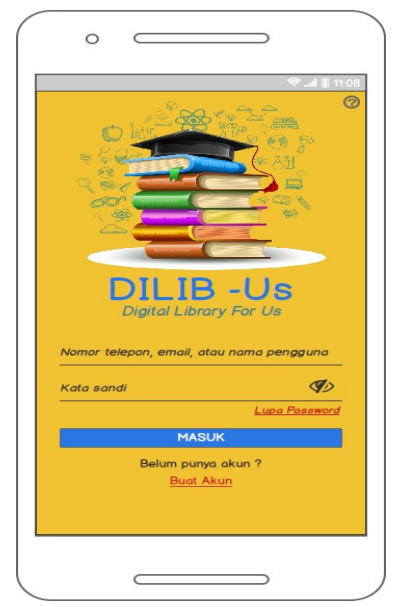

Gambar 4. Antar Muka Menu Log in User

\subsection{Dilib-Us Menu Beranda}

Menu utama yang berisi katalog, MyLibrary, Profile, Pencarian, Obrolan, Pengaturan, Tentang, Log Out

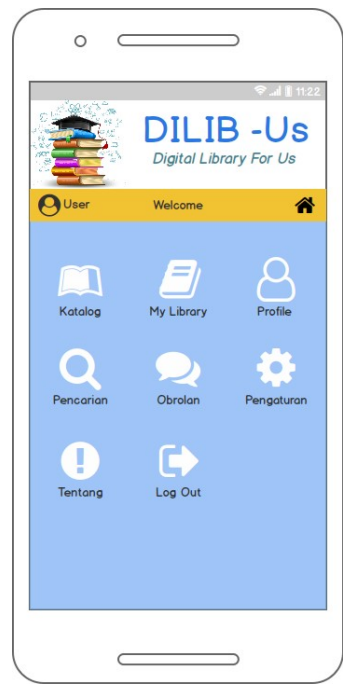

Gambar 5. Antar Muka Menu Beranda

\subsection{Dilib-Us Menu Katalog}

Menu Katalog berisi berbagai buku favorit yang dapat dipinjam oleh pengguna. Jika mengetik ikon titik tiga/kategori akan muncul berbagai kategori buku.
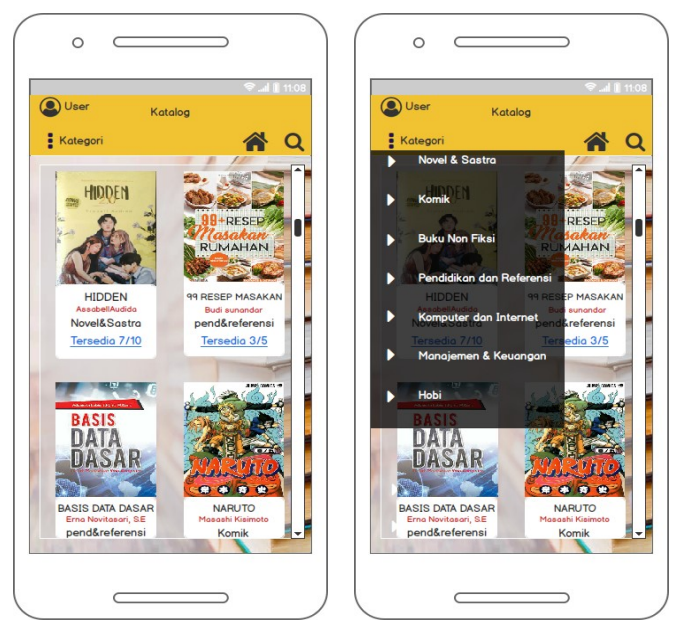

Gambar 6. Antar Muka Menu Katalog

\subsection{Dilib-Us Menu Detail Buku}

Menu detail buku berisi detail informasi buku seperti jumlah halaman, tanggal terbit, ISBN, Penerbit, dan deskripsi buku. Jika pengguna ingin meminjam buku tersebut pengguna dapat mengeklik 'Pinjam'.

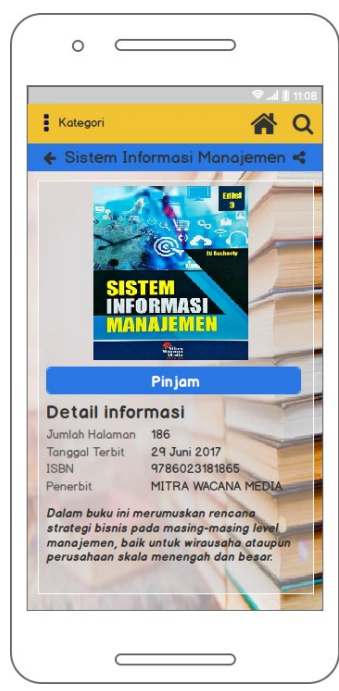

Gambar 7. Antar Muka Menu Detail Buku

\subsection{Dilib-Us Konfirmasi Peminjaman}

Menu Konfirmasi Peminjaman berisi pemberitahuan konfirmasi peminjaman buku, kemudian pengguna akan mengkonfirmasi akan meminjam atau tidak. Jika meminjam maka klik 'Iya' dan jika tidak maka klik 'Tidak'. Apabila pengguna mengkonfirmasi dengan mengeklik 'lya', maka akan muncul proses download. 

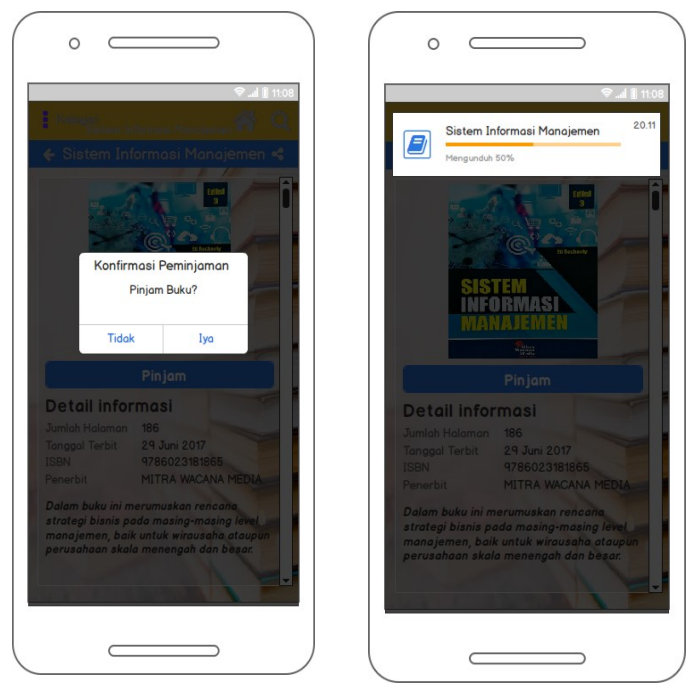

Gambar 8. Antar Muka Konfirmasi Peminjaman

\subsection{Dilib-Us Menu My Library}

My Library berisi buku yang sudah didownload atau dipinjam, dan juga berisi informasi peminjaman seperti tgl pinjam, jatuh tempo, keterlamabatan, denda, dan informasi waktu peminjaman yang tersisa. Dalam menu ini juga terdapat pilihan 'Baca Buku' dan 'Kembalikan'. Untuk pilihan Baca Buku pengguna dapat membaca buku yang telah dipinjam. Sedangkan pilihan 'Kembalikan' digunakan untuk mengembalikan buku yang sudah habis jatuh temponya ataupun sudah selesai dibaca.

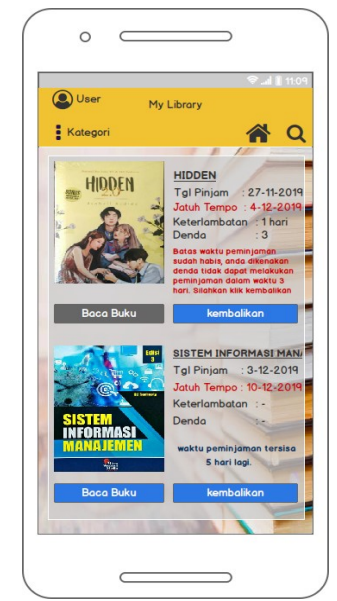

Gambar 9. Antar Muka Menu MyLibrary

\section{KESIMPULAN \& SARAN \\ Kesimpulan}

Dari hasil dan pembahasan diketahui bahwa penelitian berhasil merancang aplikasi DilibUs yang dapat mengolah data buku, data anggota, data peminjaman dan pengembalian. Kecepatan pemrosesan oleh aplikasi meningkatkan pelayanan mutu pada perpustakaan serta dapat mengurangi biaya pembuatan dokumen yang tercetak dan tempat penyimpanan buku yang terbatas. Dengan aplikasi ini, member juga dimudahkan untuk mencari buku - buku yang diinginkan dengan meminjam dan mendownload versi online tanpa harus datang ke perpustakaan sehingga hal ini dapat menghemat tenaga, waktu dan biaya.

Penggunaan model dan data memungkinkan aplikasi dapat diterapkan di berbagai jenis perpustakaan dengan kategori buku yang berbeda-beda.

\section{Saran}

Disini penulis memberikan beberapa untuk menjadi bahan pertimbangan dalam mengembangkan pelayanan dan kinerja aplikasi Dilib-Us di masa mendatang, antara lain : menambah kapasitas database untuk penyimpanan data buku yang jumlahnya juga semakin bertambah dn diharapkan petugas perpustakaan melakukan backup rutin guna mencegah data hilang apabila web server yang digunakan rusak.

\section{REFERENSI}

Hakim, R. (2012). Pengantar Sistem Informasi Bisnis. Elex Media Komputindo.

Nawi, N., \& Yuhanef, A. (2007). SISTEM eLIBRARY BERBASIS WEB DI POLITEKNIK NEGERI PADANG. TeknikA, 2(27), 18-24.

Ogedebe, P. M., \& Jacob, B. P. (2012). Software Prototyping: A Strategy to Use When User Lacks Data Processing Experience. ARPN Journal of Systems and Software, 2(6), 219-224.

Purnomo, D. (2017). Model Prototyping Pada Pengembangan Sistem Informasi. J I M $P$ - Jurnal Informatika Merdeka Pasuruan, 2(2), 54-61. https://doi.org/10.37438/jimp.v2i2.67

Ragil, W. (2010). PEDOMAN SOSIALISASI: Prosedur Operasi Standar (POS). In Mitra Wacana Media. Mitra Wacana Media. http://teknikkimia.usu.ac.id/images/PDF/L ABORATORIUM/KIMIA_ANALISA/STAN DAR_OPERASIONAL_PROSEDUR_FIX. pdf

Subrata, G. (2010). Desain Dan Standar Perpustakaan Digital. Jurnal Pustakawan Indonesia, 10(2), 1-11.

Sukaria, S. (2014). Metode Penelitian. USU Press. 